\title{
Problematika Pengaturan Syarat Pengunduran Diri Dalam Pencalonan Pemilihan Kepala Daerah di Indonesia
}

Proboroni Hastuti

Faculty of Sharia and Law, Universitas Islam Negeri Sunan Kalijaga, Yogyakarta, Indonesia

\begin{tabular}{l}
\hline Info Artikel \\
Keywords: \\
Election; Profession; \\
Resignation. \\
\\
Kata kunci: \\
Pemilihan; Profesi; \\
Pengunduran Diri. \\
Corresponding Author: \\
Proborini Hastuti, E-mail: \\
proborini.hastuti@gmail.com
\end{tabular}

\begin{abstract}
This study aims to analyze the problematic requirements for resignation in the candidacy for regional head elections in Indonesia. This research is a normative study using secondary data with primary, secondary and tertiary legal materials. The findings of this study indicate that the disparity in regulations regarding the requirements that must be met by someone from a certain profession who wants to run for regional head, be it the Governor, Regent or Mayor whose election is directly by the community. The disparity in the regulation as a condition in the nomination of regional heads in Indonesia reflects certain considerations from legislators in the provisions whether or not a person should resign from his profession if he wants to run for office.

Abstrak
Penelitian ini bertujuan untuk menganalisa problematika
syarat pengunduran diri dalam pencalonan pemilihan
kepala daerah di Indonesia. Penelitian ini merupakan
kajian normatif yang menggunakan data sekunder dengan
bahan hukum primer, sekunder dan tersier. Temuan
penelitian ini menunjukkan bahwa disparitas pengaturan
mengenai syarat yang harus dipenuhi seseorang dari
profesi tertentu yang ingin mencalonkan diri menjadi
kepala daerah, baik itu Gubernur, Bupati ataupun
Walikota yang pemilihannya secara langsung oleh
masyarakat. Disparitas pengaturan tersebut sebagai syarat
dalam pencalonan kepala daerah di Indonesia
mencerminkan adanya pertimbangan tertentu dari
pembentuk undang-undang dalam ketentuan harus
tidaknya seseorang mengundurkan diri dari profesinya
jika ingin mencalonkan diri.
\end{abstract}

\section{Pendahuluan}

Demokrasi pertama-tama merupakan gagasan yang mengandaikan bahwa kekuasaan itu adalah dari, oleh dan untuk rakyat. Dalam pengertian yang lebih partisipatif, demokrasi itu bahkan disebut sebagai konsep kekuasaan dari, oleh, untuk dan bersama rakyat. Dalam konstruksi ini, kekuasaan pada intinya diakui berasal dari rakyat, dan karena itu rakyatlah yang sebenarnya menentukan dan 
memberi nahkoda yang sesungguhnya penyelenggaraan berbangsa dan bernegara. ${ }^{1}$

Substansi UUD NRI 1945 yang terkait dengan peneguhan demokrasi juga secara gamblang disebutkan pada beberapa pasal. Pasal 1 ayat (2) UUD 1945 berbunyi, "Kedaulatan berada di tangan rakyat dan dilaksanakan menurut Undang-Undang Dasar." 2 Selain itu, wujud nyata Indonesia sebagai negara demokrasi juga bisa dilihat dalam UUD NRI 1945 yang melibatkan masyarakat langsung dalam pemilihan pejabat publik di Indonesia, seperti halnya yang diatur dalam Bab VI tentang Pemerintahan Daerah dan Bab VII B tentang Pemilihan Umum.

Negara hukum dalam pengertian state based on rule of law, rechsstaat yakni negara hukum yang demokratis, negara hukum yang berdasar hukum. ${ }^{3}$ Penegasan bahwa Indonesia sebagai Negara Hukum dapat dilihat pada Pasal 1 ayat (3) UUD 1945 yang berbunyi, "Negara Indonesia adalah Negara Hukum."4 Konsekuensi logis dari hal tersebut yaitu segala sesuatu di Indonesia berdasarkan atas peraturan yang berlaku tidak terkecuali permasalahan mengenai pemilihan kepala daerah. Pemilihan kepala daerah diartikan sebagai sarana pelaksanaan kedaulatan rakyat di wilayah provinsi dan/atau kabupaten/kota. Pengaturan organik mengenai pemilihan kepala daerah di Indonesia telah melalui jalan panjang dalam proses legitimasinya. Undangundang terakhir yang mengatur secara khusus mengenai pemilihan kepala daerah adalah Undang-Undang Nomor 10 Tahun 2016 juncto Undang-Undang Nomor 8 Tahun 2015 juncto Undang-Undang Nomor 1 Tahun 2015 tentang Penetapan Peraturan Pemerintah Pengganti Undang-Undang Nomor 1 Tahun 2014 tentang Pemilihan Gubernur, Bupati dan Walikota menjadi UndangUndang. Sehingga di titik ini, diharapkan undang-undang tersebut dapat berjalan dengan baik termasuk perihal pencalonan pemilihan kepala daerah yang merupakan pengejawantahan dari terbukanya peran masyarakat untuk turut serta dalam pemerintahan.

Pasal 28D ayat (3) UUD NRI 1945 berbunyi, "Setiap warga Negara berhak memperoleh kesempatan yang sama dalam pemerintahan." ${ }^{5}$ Pasal tersebut menunjukan bahwa setiap orang berhak ikut serta dalam pengisian jabatan publik di Indonesia, termasuk kepala daerah. Dalam proses pencalonan kepala daerah, terdapat ketentuan yang berbeda yang tersebar di beberapa peraturan

\footnotetext{
${ }^{1}$ Ahmad Zaini, "Demokrasi: Pemerintah oleh Rakyat dan Mayoritas," Al Alhkam: Jurnal Sosial, Hukum dan Keagamaan, Vol. 14 No. 2 (2018): 25-41.

2Pasal 1 ayat (2) Undang-Undang Dasar Negara Republik Indonesia Tahun 1945.

${ }^{3}$ Haposan Siallagan, "Penerapan Prinsip Negara Hukum di Indonesia," Jurnal Sosiohumaniora, Vol. 18 No. 2 (Juli 2016): 131 - 137.

4 Pasal 1 ayat (3) Undang-Undang Dasar Negara Republik Indonesia Tahun 1945.

${ }_{5}^{5}$ Pasal 28D ayat (3) Perubahan Kedua Undang-Undang Dasar Negara Republik Indonesia Tahun 1945.
} 
perundang-undangan mengenai syarat yang harus dipenuhi seseorang dari profesi tertentu yang ingin mencalonkan diri menjadi kepala daerah baik itu Gubernur, Bupati ataupun Walikota yang pemilihannya secara langsung oleh masyarakat. Profesi-profesi yang dimaksud dan yang akan dibahas dalam penelitian ini yaitu Advokat, Anggota DPR/DPD/DPRD, Notaris, PNS, POLRI, TNI dan Pegawai BUMN/BUMD dikarenakan profesi-profesi tersebut sangat dekat dengan hukum.

Adapun profesi menurut Roscoe Pound, di dalam bukunya The Lawyer From Antiquity to Modern Times bahwa "The word (proffesion) refers to a group of men pursuing a learned art as common calling in the spirit of a public service because it may incidentally be a means of liverlihood". ${ }^{6}$ Pandangan Roscoe Pound tentang pengertian profesi pada dasarnya sejalan dengan pandangan Talcott Parsons. Parsons mengemukakan bahwa "profesi" bukanlah kapitalis, pekerja (buruh), administrator pemerintah, birokrat, ataupun petani pemilik tanah. Batas lingkup profesi sebagai institusi sosial tidaklah jelas dan juga tidak tegas. Maka secara umum dapat dikatakan bahwa profesi itu menunjuk pada institusi yang terorganisasikan seputar disiplin-disiplin intelektual (yang meliputi humaniora, ilmu-ilmu alam dan ilmu-ilmu sosial), dan sistem-sistem kultural (nilai-nilai). ${ }^{7}$

Sehubungan dengan hal tersebut, terdapat perbedaan pengaturan dalam pengunduran diri beberapa profesi sebagai syarat dalam pencalonan kepala daerah di Indonesia. Pengaturan yang berbeda tersebut mencerminkan adanya pertimbangan tertentu dari pembentuk undang-undang dalam ketentuan harus tidaknya seseorang mengundurkan diri dari profesinya jika ingin mencalonkan diri dalam pemilihan kepala daerah. Sebagai contoh yakni ketentuan Pasal 7 huruf s Undang-Undang Nomor 8 Tahun 2015 juncto Undang-Undang Nomor 1 Tahun 2015 tentang Penetapan Peraturan Pemerintah Pengganti UndangUndang Nomor 1 Tahun 2014 tentang Pemilihan Gubernur, Bupati dan Walikota menjadi Undang-Undang sebelum dilakukan judicial review, telah berlaku diskriminatif terhadap sesama warga negara Indonesia yang hendak mencalonkan diri atau dicalonkan, membeda-bedakan perlakuan persyaratan antar calon. Khusus bagi anggota DPR, DPD, dan DPRD cukup hanya memberitahukan pencalonannya kepada pimpinan masing-masing, sedangkan calon yang berstatus PNS dan anggota TNI/Polri serta pejabat BUMN/BUMD harus mengundurkan diri.

Namun, pengunduran diri calon yang berstatus pejabat BUMN/BUMD adalah sejak ditetapkan sebagai calon, sedangkan pengunduran diri calon yang berstatus PNS dan anggota TNI/POLRI adalah sejak mendaftarkan diri sebagai

6Pudjo Utomo, "Peran Etika Profesi Hukum terhadap Upaya Pemberantasan Kejahatan dan Penanggulangan Kejahatan Profesi," Jurnal Ilmiah Ilmu Hukum QISTIE Vol. 12 No. 1 (Mei 2019): 34-46.

${ }^{7}$ Talcott Parsons, "Professions", Jurnal International Encyclopedia of the Social Sciences, Vol.12, (1972): 536. 
calon. Adanya putusan Mahkamah Konstitusi dalam beberapa ketentuan tersebut mengindikasikan terdapat alasan urgent mengapa hal itu perlu ditegaskan. Tentunya setelah ketentuan tersebut diubah dengan putusan Mahkamah Konstitusi, memunculkan implikasi hukum yang cukup signifikan pada profesi yang bersangkutan. ${ }^{8}$ Walapun pada akhirnya ketentuan dalam putusan tersebut telah diaplikasikan di dalam perubahan undang-undang terkait yakni di Undang-Undang Nomor 10 Tahun 2016. Berbeda dengan profesi advokat di Undang-Undang Nomor 18 Tahun 2003 tentang Advokat dan profesi notaris di Undang-Undang Nomor 30 Tahun 2004 tentang Jabatan Notaris, kedua profesi tersebut dirasa lebih ringan dalam hal persyaratan pencalonan pemilihan kepala daerah sehingga tidak terlalu berimplikasi besar terhadap profesinya. ${ }^{9}$

Sejalan dengan itu, pemilihan kepala daerah dan wakil kepala daerah bukan sekedar ajang artificial dalam mewujudkan kedaulatan rakyat. Pemilihan pemimpin lokal di tingkat provinsi, kabupaten, dan kota merupakan bagian yang sangat penting dari transformasi politik menuju konsolidasi demokrasi lokal, yang berujung pada kemampuan membentuk pemerintahan daerah yang representatif, efektif, dan pro-publik atau tidak. ${ }^{10}$ Oleh karena itu, berkualitas atau tidaknya suatu pemilihan kepala daerah sangat bergantung pada kerangka hukum dari pemilihan tersebut, termasuk dalam proses pencalonannya yang nantinya berimplikasi pada proses pemilihan kepala daerah tersebut apakah sesuai dengan koridor demokrasi yang ada atau hanya sebagai artificial kedaulatan rakyat semata. Berdasarkan uraian di atas sangatlah menarik untuk dikaji dan dianalisis lebih mendalam mengenai bagaimana dinamika pengaturan mengenai syarat pengunduran diri terhadap beberapa profesi dalam pencalonan kepala daerah di Indonesia dan bagaimana perbedaan syarat pengunduran diri tersebut jika ditinjau sebagai upaya mewujudkan pemilihan kepala daerah yang demokratis. ${ }^{11}$

\section{Metode Penelitian}

Penelitian ini merupakan penelitian normative dengan menggunakan beberapa pendekatan masalah yang meliputi pendekatan Undang-Undang

8 I.G.A.K. Rachmi Handayani, Lego Karjoko, and Abdul Kadir Jaelani, 'Model Pelaksanaan Putusan Mahkamah Konstitusi Yang Eksekutabilitas Dalam Pengujian Peraturan Perundang-

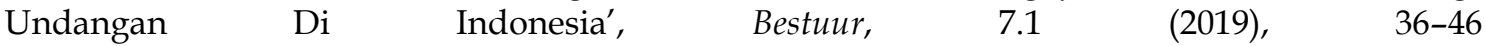
<https://jurnal.uns.ac.id/bestuur/article/view/42700>.

${ }_{9}$ Nurfaika Ishak, Rahmad Ramadhan Hasibuan, and Tri Suhendra Arbani, 'Bureaucratic and Political Collaboration Towards a Good Governance System', Bestuur, 8.1 (2020), 19 <https://doi.org/10.20961/bestuur.v8i1.42922>.

10 Veri Junaidi, "RUU Pilkada Rekayasa Setengah Hati”, Jurnal Pemilu dan Demokrasi, No. 4 (November 2012): v.

11 Prasetio and others, 'Problems of Democratic and Dignified Election in Indonesian Simultaneously Electoral Era', International Journal of Criminology and Sociology, 9 (2020), 1701-8 <https://doi.org/10.6000/1929-4409.2020.09.193>. 
(statute approach), pendekatan konseptual (conceptual approach) 12 Adapun penelitian ini menggunakan metode pengumpulan data melalui studi pustaka (library research $)^{13}$ dengan mengkonsepsikan bagaimana ketentuan perundangundangan mengenai pencalonan dalam pemilihan gubernur, bupati dan walikota yang berasal dari beberapa profesi dan dikomparasikan dengan fakta sosial yang terjadi di masyarakat dewasa ini serta menunjukkan adanya upaya dalam mewujudkan pemilihan yang demokratis. Semua data yang di himpun kemudian di analisis secara kualitatif dan deskriptif. ${ }^{14}$

\section{Pembahasan}

\section{Problematika Syarat Pengunduran Diri Dalam Pencalonan Pemilihan Kepala Daerah di Indonesia}

Pencalonan kepala daerah merupakan tahapan penting untuk seseorang dapat dipilih dalam proses pemilihan kepala daerah. Syarat pencalonan tersebut diatur di dalam Pasal 7 ayat (2) Undang-Undang Nomor 10 Tahun 2016 tentang Perubahan Kedua atas Undang-Undang Nomor 1 Tahun 2015 tentang Penetapan Peraturan Pemerintah Pengganti Undang-Undang Nomor 1 Tahun 2014 tentang Pemilihan Gubernur, Bupati, dan Walikota menjadi Undang-Undang. Adapun aturan teknis mengenai hal tersebut termuat dalam Pasal 4 Peraturan Komisi Pemilihan Umum Nomor 5 Tahun 2016 tentang Perubahan Kedua atas Peraturan Komisi Pemilihan Umum Nomor 9 Tahun 2015 tentang Pencalonan Pemilihan Gubernur dan Wakil Gubernur, Bupati dan Wakil Bupati, dan/atau Walikota dan Wakil Walikota.

Dalam syarat pencalonan kepala daerah di atas, terdapat ketentuan yang berbeda yang tersebar di beberapa peraturan perundang-undangan mengenai syarat yang harus dipenuhi seseorang dari profesi tertentu yang ingin mencalonkan diri menjadi kepala daerah baik itu Gubernur, Bupati ataupun Walikota yang pemilihannya secara langsung oleh masyarakat. Persyaratan yang dimaksud yaitu aturan mengenai pengunduran diri dari profesi tertentu. Pada poin sebelumnya telah dipaparkan bahwa yang dibahas dalam penelitian ini adalah PNS, Anggota DPR/DPD/DPRD, POLRI, TNI, Pegawai BUMN/BUMD, Advokat dan Notaris.

\section{Pegawai Negeri Sipil (PNS)}

Dalam Kamus Besar Bahasa Indonesia, "Aparatur Negara" didefinisikan sebagai "alat kelengkapan negara", terutama yang meliputi bidang

${ }^{12} \mathrm{Abdul}$ Kadir Jaelani, I Gusti Ayu Ketut Rachmi Handayani, and Lego Karjoko, 'Executability Of The Constitutional Court Decision Regarding Grace Period In The Formulation Of Legislation', International Journal of Advanced Science and Technology, 28.15 (2019), 816-23.

${ }^{13}$ Rudy Iskandar Ichlas, 'Questioning the Independence of Media Coverage in the 2019 Elections', Jurnal Bestuur, 8.1 (2020) <https:// doi.org/10.20961/ bestuur.42725>.

${ }^{14}$ Zaidah Nur Rosidah, 'Coherence of the Rules of Sharia Against Pancasila', Bestuur, 8.1 (2020), $40<$ https:// doi.org/10.20961/bestuur.v8i1.42723>. 
kelembagaan, ketatalaksanaan, dan kepegawaian, yang mempunyai tanggung jawab melaksanakan roda pemerintahan sehari-hari. ${ }^{15}$ Manajemen menitikberatkan pada kepegawaian negara dikenal dengan "profesi pegawai" yang bekerja di pemerintahan yang melaksanakan "Public Civil Servant Service" . ${ }^{16}$ Kepegawaian negara di Indonesia dikenal dengan sebutan Pegawai Negeri Sipil (selanjutnya PNS). Dahulu dikenal dengan sebutan Pamong Projo atau Pangreh Projo. Adanya Undang-Undang No. 5 Tahun 2014 tentang Aparatur Sipil Negara, kepegawaian negara yang disebut dengan istilah "aparatur sipil Negara" (selanjutnya ASN), mencakup Pegawai Negeri Sipil (PNS) dan Pegawai Pemerintah dengan Perjanjian Kerja (PPPK).

Pasal 1 angka 3 Undang-Undang Nomor 5 Tahun 2014 tentang Aparatur Sipil Negara menegaskan bahwa Pegawai Negeri Sipil yang selanjutnya disingkat PNS adalah warga negara Indonesia yang memenuhi syarat tertentu, diangkat sebagai pegawai ASN secara tetap oleh pejabat pembina kepegawaian untuk menduduki jabatan pemerintahan. Sedangkan PNS, menurut Kamus Umum Bahasa Indonesia, "pegawai" berarti "orang yang bekerja pada pemerintahan (perusahaan dan sebagainya)" sedangkan "Negeri" berarti Negara atau pemerintahan, jadi Pegawai Negeri Sipil adalah orang yang bekerja pada pemerintahan atau Negara. ${ }^{17}$

Melalui Undang-Undang Nomor 5 Tahun 2014 tentang Aparatur Sipil Negara pula, dilakukan reduksi total terhadap eksistensi Pegawai Negeri Sipil. Jika sebelumnya Pegawai Negari Sipil hanya berperan sebagai aparatur negara dan aparatur pemerintah, melalui Undang-Undang ini Pegawai Negeri Sipil diposisikan sebagai sebuah profesi yang sekaligus berperan sebagai aparatur negara dan aparatur pemerintah. Hal ini dapat dilihat dari bunyi Pasal 1 butir 1 Undang-Undang Nomor 5 Tahun 2014 tentang Aparatur Sipil Negara, yang menyebutkan bahwa, "Aparatur Sipil Negara yang selanjutnya disingkat ASN adalah profesi bagi Pegawai Negeri Sipil dan Pegawai Pemerintah dengan perjanjian kerja yang bekerja pada instansi Pemerintah", vide konsideran menimbang huruf c yang menyebutkan: ${ }^{18}$ bahwa untuk mewujudkan Aparatur Sipil Negara sebagai bagian dari reformasi birokrasi, perlu ditetapkan Aparatur Sipil Negara sebagai profesi yang memiliki kewajiban mengelola dan mengembangkan dirinya dan wajib

15 "Aparatur", Kamus Besar Bahasa Indonesia, accessed April 26, 2020, http://kbbi.web.id/aparatur.

16 "HAN Sektoral: Aparatur Sipil Negara", Sri Mamudji, accessed April 26, 2020, bem.law.ui.ac.id/fhuiguide/uploads/materi/aparatur-sipil-negara.pdf.

17 Sri Hartini, Tedi Sudrajat, Setiajeng Kadarsih, Hukum Kepegawaian di Indonesia, (Jakarta: Sinar Grafika, 2008): 31-32.

${ }^{18}$ Lihat konsideran menimbang huruf c Undang-Undang Nomor 5 Tahun 2014 tentang Aparatur Sipil Negara (Republik Indonesia, 2014). 
mempertanggungjawab-kan kinerjanya dan menerapkan prinsip merit dalam pelaksanaan manajemen Apratur Sipil Negara.

Pegawai Negeri Sipil sebagai salah satu elemen personifikasi negara, telah diberikan keistimewaan untuk perlindungan terhadap profesinya, melalui UU ASN. Dibalik maksud baik pembuatan undang-undang ini, yaitu untuk menjadikan PNS sebagai sosok yang berintegritas, profesional, netral, apolitis, bebas KKN, nasionalis, dan sebagainya. Namun demikian, terselip pasal yang menurut peneliti telah membatasi hak seseorang PNS untuk berbuat lebih jauh lagi bagi negara ini. Hal tersebut menyebabkan keadilan profesi di Indonesia dalam mengaktualisasikan dirinya tidak setara dan diskriminasi. Terutama bagi profesi PNS yang berkurang haknya untuk memperoleh kesempatan yang sama dalam pemerintahan. Pasal yang dimaksud yaitu pasal yang memuat ketentuan pengunduran diri PNS dalam pencalonan PNS menjadi kepala daerah yang tertera di Pasal 123 ayat (3) Undang-Undang Nomor 5 Tahun 2014 tentang Aparatur Sipil Negara yang berbunyi: ${ }^{19}$ Pegawai ASN dari PNS yang mencalonkan diri atau dicalonkan menjadi Presiden dan Wakil Presiden; ketua, wakil ketua, dan anggota Dewan Perwakilan Rakyat; ketua, wakil ketua, dan anggota Dewan Perwakilan Daerah; gubernur dan wakil gubernur; bupati/walikota dan wakil bupati/wakil walikota wajib menyatakan pengunduran diri secara tertulis sebagai PNS sejak mendaftar sebagai calon.

Didalam risalah dan perdebatan para pembuat Undang Undang ASN ini tidak terlihat sedikit pun adanya konsepsi filosofi dasar, argumentasi teoritis maupun aspek yuridis yang menjadi argumentasi ilmiah yang bisa dipertanggungjawabkan bagi warga negara terutama bagi profesi PNS yang profesinya harus diamputasi saat mendaftar menjadi calon kepala daerah, padahal nyata-nyata profesi dan pekerjaanya dilindungi oleh negara Pasal 27 dan Pasal 28 UUD 1945. Begitu juga halnya dalam dalam naskah akademik tidak ditemukan satu kalimatpun yang mencantumkan pokok pokok bahasan teoritik dan argumentasi ilmiah tentang hal yang menjadi landasan pijak bahwa PNS yang mencalonkan diri menjadi pejabat negara sebagaimana pasal diatas mereka wajib menyatakan mengundurkan diri secara tertulis sebagai PNS sejak mendaftar sebagai calon. ${ }^{20}$

${ }^{19}$ Lihat juga Pasal 119 Undang-Undang Nomor 5 Tahun 2014 tentang Aparatur Sipil Negara (Republik Indonesia, 2014) yang menyebutkan, "Pejabat pimpinan tinggi madya dan pejabat pimpinan tinggi pratama yang akan mencalonkan diri menjadi gubernur dan wakil gubernur, bupati/walikota, dan wakil bupati/wakil walikota wajib menyatakan pengunduran diri secara tertulis dari PNS sejak mendaftar sebagai calon. Putusan MK Nomor 41/PUU-XII/2014 juga berlaku dalam pasal ini.

${ }^{20}$ Hal inipun dijabarkan didalam Putusan Mahkamah Konstitusi 41/PUU-XII/2014 tentang Pengujian UU Aparatur Sipil Negara, hlm. 18. 
Hal ini semakin memperkuat kesan bahwa dalam penyusunan UndangUndang Nomor 5 Tahun 2014 tentang ASN ini faktor politis lebih kuat ketimbang faktor akademik ilmiah dan faktor tujuan utama dalam pembuatan Undang-Undang sebagaimana yang dikatakan oleh Jeremy Bentham bahwa tujuan dibuatnya Undang-Undang adalah memberikan kebahagiaan bagi setiap orang. Justru ketentuan tersebut membawa kesan diskriminasi terhadap PNS. Bentuk diskriminasi pasal tersebut dibuktikan oleh adanya hasil pengujian di Mahkamah Konsitusi melalui Putusan Nomor 41/PUU-XII/2014 yakni frase "sejak mendaftar sebagai calon" menjadi "sejak ditetapkan menjadi calon peserta". Putusan inipun kemudian diaplikasikan ke dalam Undang-Undang Nomor 10 Tahun 2016 tentang Perubahan Kedua atas Undang-Undang Nomor 1 Tahun 2015 tentang Penetapan Peraturan Pemerintah Pengganti Undang-Undang Nomor 1 Tahun 2014 tentang Pemilihan Gubernur, Bupati dan Walikota menjadi Undang-Undang dimana dalam Pasal 7 ayat (2) huruf $t$ bahwa PNS harus menyatakan pengunduran dirinya sejak ditetapkan menjadi pasangan calon pemilihan kepala daerah.

2. Anggota Dewan Perwakilan Rakyat/Dewan Perwakilan Daerah/Dewan Perwakilan Rakyat Daerah (DPR/DPD/DPRD)

Pasal 7 huruf s Undang-Undang Nomor 8 Tahun 2015 juncto UndangUndang Nomor 1 Tahun 2015 tentang Penetapan Peraturan Pemerintah Pengganti Undang-Undang Nomor 1 Tahun 2014 tentang Pemilihan Gubernur, Bupati dan Walikota menjadi Undang-Undang sebagaimana dirubah melalui Putusan MK Nomor 33/PUU-XIII/2015 tertanggal 8 Juli 2015 dalam amar putusannya menyatakan: ${ }^{21}$

Pasal 7 huruf s sepanjang frasa "memberitahukan pencalonannya sebagai Gubernur, Wakil Gubernur, Bupati, Wakil Bupati, Walikota, dan Wakil Walikota kepada Pimpinan Dewan Perwakilan Rakyat bagi anggota Dewan Perwakilan Rakyat, kepada Pimpinan Dewan Perwakilan Daerah bagi anggota Dewan Perwakilan Daerah, atau kepada Pimpinan Dewan Perwakilan Rakyat Daerah bagi anggota Dewan Perwakilan Rakyat Daerah" Undang-Undang Nomor 8 Tahun 2015 tentang Perubahan Atas Undang-Undang Nomor 1 Tahun 2015 tentang Penetapan Peraturan Pemerintah Pengganti Undang-Undang Nomor 1 Tahun 2014 tentang Pemilihan Gubernur, Bupati, Walikota Menjadi Undang-Undang (Lembaran Negara Republik Indonesia Tahun 2015 Nomor 57, Tambahan

21 Putusan Mahkamah Konstitusi Nomor 33/PUU-XIII/2015 perihal Pengujian UndangUndang Nomor 8 Tahun 2015 tentang Perubahan Atas Undang-Undang Nomor 1 Tahun 2015 tentang Penetapan Peraturan Pemerintah Pengganti Undang-Undang Nomor 1 Tahun 2014 tentang Pemilihan Gubernur, Bupati dan Walikota menjadi Undang-Undang terhadap UndangUndang Dasar Negara Republik Indonesia Tahun 1945, 8 Juli 2015, hlm. 160. 
Lembaran Negara Nomor 5678) tidak memiliki kekuatan hukum mengikat sepanjang tidak dimaknai, "mengundurkan diri sejak calon ditetapkan memenuhi persyaratan oleh KPU/KIP sebagai calon Gubernur, calon Wakil Gubernur, calon Bupati, calon Wakil Bupati, calon Walikota, dan calon Wakil Walikota bagi anggota Dewan Perwakilan Rakyat, anggota Dewan Perwakilan Daerah, atau anggota Dewan Perwakilan Rakyat Daerah."

Jika ditelisik lebih lanjut undang-undang Undang-Undang Nomor 8 Tahun 2015 tentang Perubahan Atas Undang-Undang Nomor 1 Tahun 2015 tentang Penetapan Peraturan Pemerintah Pengganti Undang-Undang Nomor 1 Tahun 2014 tentang Pemilihan Gubernur, Bupati, Walikota Menjadi Undang-Undang telah menetapkan bahwa hanya anggota DPR, DPD, dan DPRD yang tidak harus mengundurkan diri atau berhenti pada saat akan mendaftarkan diri sebagai calon dalam pemilihan kepala atau wakil kepala daerah. Seharusnya anggota DPR, DPD, dan DPRD tidak diperlakukan istimewa dan berbeda dengan calon lainnya seperti anggota TNI, Polri, atau pejabat BUMN/BUMD yang diwajibkan berhenti atau mengundurkan diri karena mereka semua sama dengan pegawai pemerintahan lainnya, dalam hal menerima gaji dan fasilitas lainnya dari anggaran atau keuangan negara (APBN atau APBD).

Selain itu, anggota DPR, DPD, atau DPRD memiliki hak dan kekuasaan politik dalam hal legislasi, kontrol, dan keuangan yang berpotensi dapat memengaruhi kebijakan atau pengaturan tentang pelaksanaan pemilihan melalui KPU, KPU Provinsi, maupun KPU Kabupaten/Kota serta terhadap Pemerintah atau Pemerintah Daerah. Hal ini dapat membuat adanya perlakuan yang tidak adil bagi calon lainnya dari kalangan orang biasa atau pejabat/pegawai negara lainnya yang telah mengundurkan diri atau berhenti, karena posisi anggota DPR, DPD, atau DPRD yang menjadi calon masih berstatus sebagai anggota aktif.

Kondisi tersebut berpotensi menimbulkan adanya perlakuan yang tidak sama terhadap sesama warga negara di mata hukum dalam konteks pemilihan kepala daerah dan wakil kepala daerah, yang jelas-jelas bertentangan dengan Pasal 27 ayat (1) UUD 1945. Sehingga menurut hemat peneliti, hal tersebutlah yang pada akhirnya Mahkamah Konstitusi dalam putusan sebagaimana di atas menyatakan bahwa DPR, DPD dan DPRD harus mengundurkan diri sejak ditetapkan menjadi calon peserta pemilihan kepala daerah.

3. Kepolisian Republik Indonesia (POLRI), Tentara Nasional Indonesia (TNI) dan Pegawai Badan Usaha Milik Negara/Badan Usaha Milik Daerah (Pegawai BUMN/BUMD)

Kepolisian merupakan lembaga sub sistem dalam SPP yang mempunyai kedudukan pertama dan utama. Kedudukan yang demikian oleh 
Harkristuti Harkrisnowo dikatakan sebagai the gate keeper of the criminal justice system. ${ }^{22}$ Polisi Republik Indonesia memiliki peran penting didalam masyarakat karena tugas-tugas pokoknya yang dapat menciptakan suatu kestabilan nasional yaitu sebagai pembimbing, pengayom, dan pelanyan masyarakat. Hal ini tercantum dalam Pasal 13 Undang-Undang Nomor 2 Tahun 2002 tentang Kepolisian Negara Republik Indonesia. Sejak diberlakukan Undang-Undang Nomor 2 Tahun 2002 tentang Kepolisian Negara Republik Indonesia, maka secara konstitusional telah terjadi perubahan yang menegaskan perumusan tugas, fungsi dan peran Kepolisian Negara Republik Indonesia serta pemisahan kelembagaan Tentara Nasional Indonesia dan Kepolisian Negara Republik Indonesia dengan peran dan fungsi masing-masing. Legitimasi kelembagaan TNI sendiri diatur di dalam Undang-Undang Nomor 34 Tahun 2004 tentang Tentara Nasional Indonesia.

Pasal 7 huruf $t$ Undang-Undang Nomor 8 Tahun 2015 juncto UndangUndang Nomor 1 Tahun 2015 tentang Penetapan Peraturan Pemerintah Pengganti Undang-Undang Nomor 1 Tahun 2014 tentang Pemilihan Gubernur, Bupati dan Walikota menjadi Undang-Undang telah dibatalkan melalui Putusan MK Nomor 46/PUU-XIII/2015 yang kemudian menegaskan anggota Tentara Nasional Indonesia (TNI), Kepolisian Negara Republik Indonsia (Polri), Pegawai Negeri Sipil (PNS) dan Pegawai Badan Usaha Milik Negara/Daerah (BUMN/BUMD), yang akan mencalonkan diri menjadi kepala daerah tidak perlu mundur dari jabatannya sebelum dinyatakan memenuhi persyaratan oleh penyelenggara Pilkada sebagai calon..$^{23}$

Ketentuan pasal yang diujikan dalam putusan MK tersebut yang memberikan kelonggaran bagi anggota DPR, DPD, dan DPRD hanya cukup dengan pemberitahuan kepada pimpinannya jika mencalonkan diri dalam pemilihan kepala daerah dan wakil kepala daerah secara nyata merupakan sebuah tindakan yang tidak adil dan melanggar prinsip keadilan (fairness) bagi calon lainnya yang sama-sama digaji dan difasilitasi dari uang negara seperti anggota TNI, Polri, atau pejabat BUMN/BUMD. Seharusnya anggota DPR, DPD, atau DPRD juga harus mengundurkan diri sejak ditetapkan sebagai calon kepala atau wakil kepala daerah sebagaimana anggota TNI, Polri, atau pejabat BUMN/BUMD karena sama-sama sebagai

${ }^{22}$ Agus Rahardjo, "Profesionalisme Polisi dalam Penegakan Hukum," Jurnal Dinamika Hukum Vo. 11 No. 3 (September 2011): 391.

${ }_{23}$ Putusan Mahkamah Konstitusi Nomor 46/PUU-XIII/2015 perihal Pengujian UndangUndang Nomor 8 Tahun 2015 tentang Perubahan Atas Undang-Undang Nomor 1 Tahun 2015 tentang Penetapan Peraturan Pemerintah Pengganti Undang-Undang Nomor 1 Tahun 2014 tentang Pemilihan Gubernur, Bupati dan Walikota menjadi Undang-Undang terhadap UndangUndang Dasar Negara Republik Indonesia Tahun 1945, 8 Juli 2015, hlm. 69. 
pejabat publik yang dibiayai oleh Negara baik secara langsung maupun tidak langsung agar tidak terjadi konflik kepentingan.

Bahwa seandainya pun dikatakan bahwa anggota DPR, DPD, dan DPRD berbeda dengan anggota TNI, Polri, atau pejabat BUMN/BUMD karena yang pertama merupakan pejabat atau penyelenggara negara yang dipilih secara langsung oleh rakyat (elected), sedangkan yang kelompok terakhir merupakan jabatan atau posisi yang berasal dari penunjukan (appointed), hal tersebut tidak menghilangkan substansi persamaan kedua jenis kelompok tersebut dalam hal sama-sama sebagai Pejabat Negara atau setidaknya sebagai penyelenggara negara sebagaimana dimaksud dalam UU Aparatur Sipil Negara dan UU Pemerintahan Daerah, serta sama-sama pula dibiayai oleh Negara. Bahkan seharusnya anggota DPR, DPD, atau DPRD mempertimbangkan hasil Pemilihan Umum yang telah menempatkan mereka sebagai Pejabat Negara atau Penyelenggara Pemerintahan Daerah di mana mereka telah mendapatkan mandat rakyat sebagai wakil rakyat dan penyuara kepentingan rakyat di daerah pemilihannya masing-masing. Selain itu, Pasal 122 huruf $\mathrm{c}$ dan huruf d UU Nomor 5 Tahun 2014 tentang Aparatur Sipil Negara telah menempatkan anggota DPR dan DPD sebagai Pejabat Negara, setara secara hukum dengan posisi Presiden, Wakil Presiden, Menteri, Ketua Mahkamah Agung, Ketua Mahkamah Konstitusi, Ketua Lembaga Negara lainnya, Gubernur, Bupati, atau Walikota.

\section{Advokat}

Pasal 20 ayat (3) Undang-Undang Nomor 18 Tahun 2003 tentang Advokat yang berbunyi, "Advokat yang menjadi pejabat Negara tidak melaksanakan tugas profesi Advokat selama memangku jabatan tersebut." ${ }^{24}$ Ketentuan di atas memperlihatkan bahwa advokat yang mencalonkan diri atau dicalonkan menjadi pejabat negara tidak berhenti dari profesi keadvokatannya dan tidak mewajibkan advokat untuk berhenti dari profesinya. Ketentuan tersebut hanya memuat bahwa advokat tidak diperbolehkan melaksanakan tugas profesi advokat "selama memangku jabatan Negara", artinya jika tidak menjadi pejabat negara lagi mereka bisa otomatis kembali menjadi advokat. ${ }^{25}$

Menurut hemat peneliti, hal tersebut didasarkan karena profesi advocat bukan termasuk pejabat negara. Advocat adalah sebuah profesi yang independen dan officium nobile. Profesi Advocat melekat seumur hidup sedangkan pejabat negara hanya dalam suatu waktu tertentu. Sehingga

${ }^{24}$ Pasal 20 ayat (3) Undang-Undang Nomor 18 Tahun 2003 tentang Advokat (Republik Indonesia, 2003).

${ }^{25}$ Lihat lebih lanjut dalam Undang-Undang Nomor 18 Tahun 2003 tentang Advokat (Republik Indonesia, 2003). 
inilah yang membuat seseorang yang berprofesi advocat tidak perlu mengundurkan diri sebagai advocat saat mengikuti pencalonan kepala daerah.

\section{Notaris}

Pasal 11 Undang-Undang Nomor 30 Tahun 2004 tentang Jabatan Notaris menyebutkan:26

Pasal 11

Notaris yang diangkat menjadi pejabat negara wajib mengambil cuti.

(1) Cuti sebagaimana dimaksud pada ayat (1) berlaku selama Notaris memangku jabatan sebagai pejabat negara.

(2) Notaris sebagaimana dimaksud pada ayat (1) wajib menunjuk Notaris Pengganti.

(3) Apabila Notaris tidak menunjuk Notaris Pengganti sebagaimana dimaksud pada ayat (3), Majelis Pengawas Daerah menunjuk Notaris lain untuk menerima Protokol Notaris yang daerah hukumnya meliputi tempat kedudukan Notaris yang diangkat menjadi pejabat negara.

(4) Notaris yang ditunjuk sebagaimana dimaksud pada ayat (4) merupakan pemegang sementara Protokol Notaris.

(5) Notaris yang tidak lagi menjabat sebagai pejabat negara sebagaimana dimaksud pada ayat (1) dapat menjalankan kembali jabatan Notaris dan Protokol Notaris sebagaimana dimaksud pada ayat (4) diserahkan kembali kepadanya.

Dalam undang-undang ini, terlihat bahwa notaris diakui dan dilindungi hak warga negaranya dalam hal menjalankan profesi dan hak berpolitiknya untuk menduduki jabatan negara. Tidak ada klausul yang mewajibkan profesi notaris untuk menyatakan pengunduran diri dari profesinya secara tertulis jika mencalonkan diri atau dicalonkan untuk menduduki jabatan Negara, hanya saja diwajibkan untuk cuti selama memangku jabatan Negara dan dipulihkan kembali profesi notarisnya jika sudah tidak mengabdi menjadi pejabat Negara.

Perlu diketahui bersama bahwa jabatan notaris merupakan suatu lembaga yang diciptakan oleh negara yang baik kewenangan atau materi muatannya tidak berdasarkan pada peraturan perundang-undangan, delegasi atau mandat, melainkan berdasarkan wewenang yang timbul dari freis ermessen yang dilekatkan pada administrasi negara untuk

26 Pasal 11 Undang-Undang Nomor 30 Tahun 2004 tentang Jabatan Notaris (Republik Indonesia, 2004). 
mewujudkan suatu tujuan yang dibenarkan oleh hukum. ${ }^{27}$ Maka berdasarkan kewenangan dari notaris itulah yang memunculkan ketentuan bahwa notaris hanya mengambil cuti saat notaris tersebut ingin mencalonkan diri dalam pemilihan kepala daerah.

\section{Disparitas Pengaturan Mengenai Syarat Pengunduran Diri dalam Pencalonan Kepala Daerah sebagai Upaya Mewujudkan Pemilihan yang Demokratis}

Dalam era demokrasi pasca reformasi di Indonesia kini, setiap warga negara diberikan hak untuk memperoleh kesempatan yang sama dalam pemerintahan yang mana hal ini merupakan salah satu hak asasi manusia yang dijamin di dalam Undang-Undang Dasar Negara Republik Indonesia Tahun 1945 sebagaimana yang tercantum di dalam Pasal 28D ayat (3). Walaupun suatu hak dapat dibatasi oleh undang-undang, tapi hendaknya pembatasan tersebut tidak mengandung unsur diskriminasi. Hal ini merupakan salah satu bagian untuk mewujudkan kehidupan bangsa Indonesia yang lebih demokratis serta menjunjung tinggi kedaulatan rakyat, aspirasi, keterbukaan, keadilan, tanggung jawab, dan perlakuan yang tidak diskriminatif.

Salah satu ciri dari negara demokrasi adalah melaksanakan pemilihan umum dalam waktu-waktu tertentu yang dalam proses pelaksanaannya diselenggarakan secara demokratis. Pemilihan umum pada hakikatnya merupakan pengakuan dan perwujudan daripada hak-hak politik rakyat dan sekaligus merupakan pendelegasian hak-hak tersebut oleh rakyat kepada wakilwakilnya untuk menjalankan pemerintahan. ${ }^{28}$ Rusli Karim berpendapat bahwa pemilihan umum merupakan salah satu sarana utama untuk menegakkan tatanan demokrasi (kedaulatan rakyat), yang berfungsi sebagai alat menyehatkan dan menyempurnakan demokrasi, bukan sebagai tujuan demokrasi. ${ }^{29}$

Pemilihan kepala daerah secara langsung adalah salah satu perwujudan instrumen demokrasi dalam rangka menciptakan pemerintah yang lebih demokratis. Dengan sistem ini, maka harapan terwujudnya kedaulatan rakyat dalam sistem pemerintahan diyakini dapat terealisasi secara menyeluruh, mengingat sistem demokrasi merupakan perintah langsung yang diamanatkan oleh UUD 1945. Sejalan dengan itu, pemilihan kepala daerah dan wakil kepala daerah bukan sekedar ajang artificial dalam mewujudkan kedaulatan rakyat. Pemilihan pemimpin lokal di tingkat provinsi, kabupaten, dan kota merupakan bagian yang sangat penting dari transformasi politik menuju konsolidasi

27 "Matriks Makalah Politik Hukum tentang Kedudukan Notaris selama Menjadi Anggota Dewan Perwakilan Rakyat", Magister Notariat UNTAG Semarang, accessed May 7, 2020 http://newprediksiemas.blogspot.co.id/.

28 Titik Triwulan Tutik, Konstruksi Hukum Tata Negara Indonesia pasca Amandemen UUD 1945, (Jakarta: Kencana Prenada Media, 2010): 329.

29 Ibid. 
demokrasi lokal, yang berujung pada kemampuan membentuk pemerintahan daerah yang representatif, efektif, dan pro-publik atau tidak. ${ }^{30}$ Oleh karena itu, berkualitas atau tidaknya suatu pemilihan kepala daerah sangat bergantung pada kerangka hukum dari pemilihan tersebut, termasuk dalam proses pencalonannya yang nantinya berimplikasi pada proses pemilihan kepala daerah tersebut apakah sesuai dengan koridor demokrasi yang ada atau hanya sebagai artificial kedaulatan rakyat semata.

Tahap pencalonan kepala daerah adalah salah satu tahapan paling krusial dalam penyelenggaraan pemilihan Gubernur, Bupati dan Walikota. Esensi dari menghadirkan pilihan yang akan dihadapkan kepada pemilih hanya ada di dalam tahapan pencalonan kepala daerah. Adapun proses pencalonan kepala daerah, terbagi dalam dua pengelompokan utama yang harus dipenuhi. Pertama, hal yang harus dipenuhi oleh individu orang yang akan menjadi calon kepala daerah. Kedua, syarat pencalonan yang harus dipenuhi oleh pihak yang akan mengusung dan mengajukan individu bakal calon kepala daerah tersebut. ${ }^{31}$

Salah satu proses yang menarik dalam pemenuhan syarat pencalonan oleh pihak yang mengajukan menjadi bakal calon kepala daerah sebagaimana dijabarkan dalam poin sebelumnya mengenai pengunduran diri pihak terkait dalam profesinya. Dinamika yang terjadi dalam pengaturannya terjadi pada tataran jabatan publik dimana sebelum ada Putusan Mahkamah Konstitusi Nomor 41/PUU-XII/2014, Nomor 33/PUU-XIII/ 2015 dan Nomor 46/PUUXIII/2015 ada perbedaan perlakuan terhadap profesi PNS, TNI/POLRI, Pegawai BUMN/BUMD dan anggota DPR/DPRD/DPD. Hal ini berbeda dengan profesi Advokat dan Notaris. ${ }^{32}$ Adapun dinamika aturan pengunduran diri tersebut dapat terlihat dalam tabel di bawah ini:

\begin{tabular}{|l|c|c|c|}
\hline \multicolumn{2}{|c|}{ Latar Belakang Calon } & \multicolumn{2}{c|}{ Syarat Calon* } \\
\hline \multicolumn{1}{|c|}{ Peraturan } & Profesi & $\begin{array}{c}\text { Sebelum } \\
\text { Putusan MK }\end{array}$ & $\begin{array}{c}\text { Setelah } \\
\text { Putusan MK }\end{array}$ \\
\hline $\begin{array}{l}\text { UU No. 8 Tahun 2015; } \\
\text { dan } \\
\text { UU No. 5 Tahun 2014; }\end{array}$ & PNS & MD & MC \\
\hline $\begin{array}{l}\text { UU No. 34 Tahun 2004; } \\
\text { atau } \\
\begin{array}{l}\text { UU No. 2 Tahun 2002; } \\
\text { dan }\end{array}\end{array}$ & TNI/POLRI & MD & MC \\
\hline
\end{tabular}

${ }^{30}$ Veri Junaidi, "RUU Pilkada Rekayasa Setengah Hati", Jurnal Pemilu dan Demokrasi, No. 4 (November 2012): v.

${ }^{31}$ Fadli Ramadhanil, "Catatan Proses Pencalonan Pemilihan Kepala Daerah Tahun 2015 dan Sengketa Kepengurusan Partai Politik," Jurnal Pemilu dan Demokrasi, Vol. 8 (April 2016): 65.

${ }^{32} \mathrm{M}$ Jamil, 'Pemalsuan Akta Autentik Sebagai Aspek Pidana Notaris', Bestuur, 7.2 (2019). 


\begin{tabular}{|c|c|c|c|}
\hline UU No. 8 Tahun 2015 & & & \\
\hline UU No. 8 Tahun 2015 & $\begin{array}{c}\text { Pegawai } \\
\text { BUMN/ } \\
\text { BUMD }\end{array}$ & $\mathrm{MC}$ & $\mathrm{MC}$ \\
\hline UU No. 8 Tahun 2015 & $\begin{array}{l}\text { Anggota } \\
\text { DPR/ } \\
\text { DPRD/ } \\
\text { DPD }\end{array}$ & $\begin{array}{l}\text { Melapor pada } \\
\text { pimpinan }\end{array}$ & $\mathrm{MC}$ \\
\hline $\begin{array}{l}\text { UU No. } 18 \text { Tahun } 2003 \\
\text { UU No. } 8 \text { Tahun } 2015\end{array}$ & Advokat & $\begin{array}{c}\text { Berhenti } \\
\text { Sementara }\end{array}$ & $\begin{array}{c}\text { Berhenti } \\
\text { Sementara }\end{array}$ \\
\hline $\begin{array}{l}\text { UU No. } 30 \text { Tahun } 2004 \\
\text { UU No. } 8 \text { Tahun } 2015\end{array}$ & Notaris & Wajib Cuti & Wajib Cuti \\
\hline
\end{tabular}

*Keterangan:

MD (Mundur saat mendaftar sebagai calon)

MC (Mundur saat ditetapkan sebagai calon)

Pada akhirnya, putusan MK seperti yang disebutkan di atas diejawantahkan di dalam UU No. 10 Tahun 2016 tentang Perubahan Kedua UU No. 1 Tahun 2015 tentang Penetapan Peraturan Pemerintah Pengganti Undang-Undang Nomor 1 Tahun 2014 tentang Pemilihan Gubernur, Bupati dan Walikota menjadi UndangUndang serta diejawantahkan pula di dalam Peraturan KPU No. 5 Tahun 2016 tentang Perubahan Kedua atas Peraturan KPU No. 9 Tahun 2015 tentang Pencalonan Pemilihan Gubernur dan Wakil Gubernur, Bupati dan Wakil Bupati, dan/atau Walikota dan Wakil Walikota. Jika ditelisik lebih lanjut, bahwa perbedaan ketentuan di atas menurut peneliti dipengaruhi oleh beberapa faktor yaitu: ${ }^{33}$

1. Darimana sumber penghasilan dan fasilitas yang didapat dari profesi tersebut (APBN/APBD/lainnya)

2. Apakah perkerjaan dari profesi tersebut berkaitan dengan pelayanan kepada masyarakat

3. Apakah ada kerentanan abuse of power

Hubungan faktor-faktor di atas jika dikaitkan dengan persoalan perbedaan syarat pengunduran diri dari beberapa profesi, menurut hemat peneliti dapat dijabarkan sebagai berikut: ${ }^{34}$

${ }^{33}$ C.D. Balenina, 'Partisipasi Masyarakat Dalam Pengelolaan Desa Sampah Mandiri Di Desa Kalisoro, Tawangmangu, Kabupaten Karanganyar', Bestuur, 7.1 (2019), 26-35 <https://doi.org/https://dx.doi.org/10.20961/bestuur.v7i1.28418>.

${ }^{34}$ RD Saputra, Rian, Luthviat, 'Institutionalization of the Approval Principle of Majority Creditors for Bankruptcy Decisions in Bankruptcy Act Reform Efforts', Journal of Morality and Legal Culture, 1.2 (2020), 93-102 <https:/ / doi.org/10.20961/jmail.17i1.41087>. 
1. Penghasilan dari suatu profesi yang berasal dari APBN/APBD mengartikan bahwa profesi tersebut digaji dan difasilitasi untuk memperlancar tugasnya dari Negara. Jika profesi tersebut tidak mengundurkan diri, power tends to corrupt tentu tidak bisa dihindari. Berbeda dengan profesi advokat dan notaris dimana penghasilannya di dapat bukan dari APBN secara langsung sehingga power tends to corrupt cenderung tidak ada sehingga tidak perlu untuk berhenti dari profesinya. ${ }^{35}$

2. Profesi PNS, TNI/POLRI, Anggota DPR/DPD/DPRD, pegawai BUMN/BUMD sangat dekat dengan fungsinya dalam pelayanan masyarakat. Simplifikasinya, seseorang yang berprofesi salah satu diantaranya yang mencalonkan diri menjadi kepala daerah tentunya tidak dapat menjalankan fungsi pelayanan masyarakat. Sehingga jelas, seseorang tersebut tidak bisa melaksanakan tanggungjawabnya sehingga mau tidak mau yang bersangkutan wajib mengundurkan diri. Jika dibandingkan dengan profesi advokat dan notaris dimana mereka menjalankan pekerjaannya sebagai praktisi hukum tidak langsung bersentuhan dengan pelayanan masyarakat secara umum, sehingga implikasi langsung dari kedua profesi tersebut jika mencalonkan diri menjadi kepala daerah tidak serta merta merugikan masyarakat, tetapi justru mereka hanya terhambat menjalankan pekerjaannya sebagai praktisi hukum. Dengan demikian, mereka hanya "tidak aktif" menjalankan pekerjaannya, sehingga tidak perlu mengundurkan diri. ${ }^{36}$

3. Seperti halnya poin pertama, bahwa profesi yang sumber penghasilannya dari APBN/APBN tentu akan memiliki kewenangan dari Negara. Artinya, jika seseorang dari profesi tersebut mencalonkan diri menjadi kepala daerah dan menjalankan kampanye, kerentanan abuse of power sangat besar karena ketiadaan pengaturan pengunduran diri. Karena diakui atau tidak, kewenangan profesi-profesi tersebut lebih luas daripada profesi seperti advokat dan notaris. Kerentanan kerugian Negara pun sebuah keniscayaan dapat terjadi. Dengan demikian, sangat wajar bila profesi yang berasal dari APBN/APBD tersebut harus mengundurkan diri.

Merujuk pada penjabaran di atas, bahwa perbedaan aturan pengunduran diri dari beberapa profesi dalam pencalonan kepala daerah adalah salah satu political order untuk mendukung adanya demokratisasi dalam pemilihan kepala daerah

35 Proborini Hastuti, ‘Desentralisasi Fiskal Dan Stabilitas Politik Dalam Kerangka Pelaksanaan Otonomi Daerah Di Indonesia', Simposium Nasional Keuangan Negara, 2018, 784-99.

${ }^{36}$ Proborini Hastuti and Gunung Anyar, 'The Reduction of Administrative Government ' S Atribution Authority in Village Chief Election', 6, 2018, 113-30. 
(Gubernur, Bupati ataupun Walikota). ${ }^{37}$ Afan Gaffar menyatakan beberapa persyaratan untuk mengamati apakah sebuah political order merupakan sistem yang demokratis atau tidak, diantaranya; pertama, yaitu adanya rekrutmen politik yang terbuka. Artinya, setiap orang yang memenuhi syarat untuk mengisi suatu jabatan politik yang dipilih oleh rakyat mempunyai peluang yang sama dalam kompetisi untuk mengisi jabatan tersebut. Dalam negara yang tidak demokratis, rekrutmen politik biasanya dilakukan secara tertutup yang hanya dinikmati oleh segelintir orang saja. ${ }^{38}$

Kedua, masyarakat menikmati hak-hak dasar, karena dalam suatu negara yang demokratis, setiap warga masyarakat dapat menikmati hak-hak dasar mereka secara bebas, termasuk di dalamnya hak menyatakan pendapat, hak berkumpul dan berserikat dan hak menikmati pers yang bebas. ${ }^{39}$ Dalam hal ini hak untuk menyatakan pendapat dapat digunakan seseorang untuk menentukan preferensi politiknya, tentang suatu masalah, terutama menyangkut dirinya dan masyarakat sekitarnya, dengan kata lain seseorang tersebut punya hak untuk ikut menentukan agenda yang diperlukan. Merujuk pada berbagai kebijakan tersebut, diharapkan equality of political states dapat terlaksana dan kontestasi pemilihan kepala daerah baik Gubernur, Bupati dan Walikota yang adil dan demokratis dapat terwujud. ${ }^{40}$

\section{Penutup}

Dinamika pengaturan syarat pengunduran diri terhadap PNS, Anggota DPR/DPRD/DPD, TNI, POLRI dan Pegawai BUMN/BUMD akhirnya secara eksplisit diatur dalam Pasal 7 ayat (2) huruf s, huruf $t$ dan huruf $u$ UndangUndang Nomor 10 Tahun 2016 tentang Perubahan Kedua atas Undang-Undang Nomor 1 Tahun 2015 tentang Penetapan Peraturan Pemerintah Pengganti Undang-Undang Nomor 1 Tahun 2014 tentang Pemilihan Gubernur, Bupati, dan Walikota menjadi Undang-Undang. Sedangkan profesi Adokat diatur di dalam Pasal 20 ayat (3) Undang-Undang Nomor 18 Tahun 2003 tentang Advokat dan Notaris diatur di dalam Pasal 11 Undang-Undang Nomor 30 Tahun 2004 tentang Jabatan Notaris. Adapun perbedaan syarat pengunduran diri dari beberapa profesi merupakan political order untuk mendukung adanya demokratisasi dalam

\footnotetext{
37Proborini Hastuti, 'Shifting the Character of the Constitutional Court Decision Influenced by Political Constellation in Indonesia', Constitutional Review, 5.2 (2019), 330 <https://doi.org/10.31078/consrev526>.

${ }^{38}$ Muhamad Mahrus Setia Wijaksana, 'Implementation of Criminal Case Trials Through a Teleconference by Prosecutors with a Progressive Legal Approach Muhamad', Journal of Mo, 1.2 (2020), 93-102 <https://doi.org/10.20961/jmail.17i1.41087>.

${ }^{39}$ Hastuti and Anyar.

${ }^{40}$ I Dewa Made Suartha, 'Criminal Policy Formulation on Regulation of Death Penalties for Criminal Actors', Journal of Morality and Legal Culture, 1.1 (2020), 12 $<$ https://doi.org/10.20961/jmail.v1i1.44743>.
} 
pemilihan kepala daerah (Gubernur, Bupati ataupun Walikota) supaya tercipta equality of political states dan terwujudnya kontestasi pemilihan kepala daerah baik Gubernur, Bupati dan Walikota yang adil dan demokratis. Dalam rangka memaksimalkan penerapan prinsip negara hukum Indonesia, maka kiranya dalam setiap pelaksanaannya dapat diwujudkan secara konsisten. Melalui konsistensi penerappan rinsip negara hukum bagi Indonesia, akan terwujud tujuan negara hukum yang dikehendaki bangsa Indonesia itu sendiri. Negara hukum bukan hanya urgen dalam tataran konsep, namun sangat urgen dalam tataran praktik. Oleh sebab itu, konsistensi penerapannya menjadi sangat dibutuhkan dan bahkan merupakan suatu keharusan agar membawa manfaat besar bagi kehidupan berbangsa dan bernegara.

\section{Refrences}

Balenina, C.D., 'Partisipasi Masyarakat Dalam Pengelolaan Desa Sampah Mandiri Di Desa Kalisoro, Tawangmangu, Kabupaten Karanganyar', $\begin{array}{llll}\text { Bestuur, } & 7.1 & \text { (2019), }\end{array}$ <https://doi.org/https://dx.doi.org/10.20961/ bestuur.v7i1.28418>

Handayani, I.G.A.K. Rachmi, Lego Karjoko, and Abdul Kadir Jaelani, 'Model Pelaksanaan Putusan Mahkamah Konstitusi Yang Eksekutabilitas Dalam Pengujian Peraturan Perundang-Undangan Di Indonesia', Bestuur, 7.1 (2019), 36-46 <https://jurnal.uns.ac.id/bestuur/article/view/42700>

Hastuti, Proborini, 'Desentralisasi Fiskal Dan Stabilitas Politik Dalam Kerangka Pelaksanaan Otonomi Daerah Di Indonesia', Simposium Nasional Keuangan Negara, 2018, 784-99

- - - , 'Shifting the Character of the Constitutional Court Decision Influenced by Political Constellation in Indonesia', Constitutional Review, 5.2 (2019), 330 <https://doi.org/10.31078/consrev526>

Hastuti, Proborini, and Gunung Anyar, 'The Reduction of Administrative Government' S Atribution Authority in Village Chief Election', 6, 2018, 11330

Ichlas, Rudy Iskandar, 'Questioning the Independence of Media Coverage in the 2019 Elections', Jurnal Bestuur, $8.1 \quad$ (2020) <https://doi.org/10.20961/bestuur.42725>

Ishak, Nurfaika, Rahmad Ramadhan Hasibuan, and Tri Suhendra Arbani, ‘Bureaucratic and Political Collaboration Towards a Good Governance System', Bestuur, 8.1

(2020),

<https://doi.org/10.20961/bestuur.v8i1.42922>

Jaelani, Abdul Kadir, I Gusti Ayu Ketut Rachmi Handayani, and Lego Karjoko, 'EXECUTABILITY OF THE CONSTITUTIONAL COURT DECISION REGARDING GRACE PERIOD IN THE FORMULATION OF 
LEGISLATION', International Journal of Advanced Science and Technology, 28.15 (2019), 816-23

Jamil, M, 'Pemalsuan Akta Autentik Sebagai Aspek Pidana Notaris', Bestuur, 7.2 (2019)

Muhamad Mahrus Setia Wijaksana, 'Implementation of Criminal Case Trials Through a Teleconference by Prosecutors with a Progressive Legal Approach Muhamad', Journal of Mo, 1.2 (2020), 93-102 <https:/ / doi.org/10.20961/jmail.17i1.41087>

Prasetio, Lego Karjoko, Lita Tyesta Addy Listya Wardhani, Siti Marwiyah, I. Gusti Ayu Ketut Rachmi Handayani, Abdul Kadir Jaelani, and others, 'Problems of Democratic and Dignified Election in Indonesian Simultaneously Electoral Era', International Journal of Criminology and Sociology, 9 (2020), 1701-8 <https://doi.org/10.6000/19294409.2020.09.193>

Rosidah, Zaidah Nur, 'Coherence of the Rules of Sharia Against Pancasila', Bestuur, 8.1 (2020), 40 <https:// doi.org/10.20961/ bestuur.v8i1.42723>

Saputra, Rian, Luthviat, RD, 'Institutionalization of the Approval Principle of Majority Creditors for Bankruptcy Decisions in Bankruptcy Act Reform Efforts', Journal of Morality and Legal Culture, 1.2 (2020), 93-102 <https://doi.org/10.20961/jmail.17i1.41087>

Suartha, I Dewa Made, 'Criminal Policy Formulation on Regulation of Death Penalties for Criminal Actors', Journal of Morality and Legal Culture, 1.1 (2020), 12 <https:/ / doi.org/10.20961/jmail.v1i1.44743>

Asshiddiqie, Jimly. Hukum Tata Negara dan Pilar-Pilar Demokrasi. Jakarta: Konstitusi Press, 2005.

Undang-Undang Dasar Negara Republik Indonesia Tahun 1945. Republik Indonesia, 1945.

Hajon M., Philipus. Perlindungan Hukum bagi Rakyat di Indonesia. Surabaya: Bina Ilmu, 1987.

Wirjanto, Soemarno P. “Ilmu Hukum Profesi”, Jurnal Pro Justitia, No. 11 (1980): 849.

Parsons, Talcott. "Professions", Jurnal International Encyclopedia of the Social Sciences, Vol.12, (1972): 536.

Junaidi, Veri. "RUU Pilkada Rekayasa Setengah Hati", Jurnal Pemilu dan Demokrasi, No. 4 (November 2012): v.

Marzuki, Peter Mahmud. Penelitian Hukum, Cet. 2. Jakarta: Kencana, 2008.

Soekanto, Soerjono dan Sri Mamudji, Penelitian Hukum Normatif: Suatu Tinjauan Singkat, Cet. 8. Jakarta: PT. Raja Drafindo Persada, 2006.

"Aparatur", Kamus Besar Bahasa Indonesia, accessed April 26, 2020, http://kbbi.web.id/aparatur. 
“HAN Sektoral: Aparatur Sipil Negara." Sri Mamudji. Accessed April 26, 2020. bem.law.ui.ac.id/fhuiguide/uploads/materi/aparatur-sipil-negara.pdf.

Hartini, Sri, Tedi Sudrajat, Setiajeng Kadarsih. Hukum Kepegawaian di Indonesia. Jakarta: Sinar Grafika, 2008.

Undang-Undang Nomor 5 Tahun 2014 tentang Aparatur Sipil Negara (Republik Indonesia, 2014).

Rahardjo, Agus. "Profesionalisme Polisi dalam Penegakan Hukum." Jurnal Dinamika Hukum Vo. 11 No. 3 (September 2011): 391.

Undang-Undang Nomor 18 Tahun 2003 tentang Advokat (Republik Indonesia, 2003).

Undang-Undang Nomor 30 Tahun 2004 tentang Jabatan Notaris (Republik Indonesia, 2004).

"Matriks Makalah Politik Hukum tentang Kedudukan Notaris selama Menjadi Anggota Dewan Perwakilan Rakyat", Magister Notariat UNTAG Semarang, accessed May 7, 2020 http://newprediksiemas.blogspot.co.id/.

Titik Triwulan Tutik, Konstruksi Hukum Tata Negara Indonesia pasca Amandemen UUD 1945, (Jakarta: Kencana Prenada Media, 2010): 329.

Veri Junaidi, "RUU Pilkada Rekayasa Setengah Hati", Jurnal Pemilu dan Demokrasi, No. 4 (November 2012): v.

Fadli Ramadhanil, "Catatan Proses Pencalonan Pemilihan Kepala Daerah Tahun 2015 dan Sengketa Kepengurusan Partai Politik," Jurnal Pemilu dan Demokrasi, Vol. 8 (April 2016): 65.

Putusan Mahkamah Konstitusi Nomor 41/PUU-XII/2014 perihal Pengujian Undang-Undang Nomor 5 Tahun 2014 tentang Aparatur Sipil Negara terhadap Undang-Undang Dasar Negara Republik Indonesia Tahun 1945, 8 Juli 2015

Putusan Mahkamah Konstitusi Nomor 33/PUU-XIII/2015 perihal Pengujian Undang-Undang Nomor 8 Tahun 2015 tentang Perubahan Atas UndangUndang Nomor 1 Tahun 2015 tentang Penetapan Peraturan Pemerintah Pengganti Undang-Undang Nomor 1 Tahun 2014 tentang Pemilihan Gubernur, Bupati dan Walikota menjadi Undang-Undang terhadap Undang-Undang Dasar Negara Republik Indonesia Tahun 1945, 8 Juli 2015.

Putusan Mahkamah Konstitusi Nomor 46/PUU-XIII/2015 perihal Pengujian Undang-Undang Nomor 8 Tahun 2015 tentang Perubahan Atas UndangUndang Nomor 1 Tahun 2015 tentang Penetapan Peraturan Pemerintah Pengganti Undang-Undang Nomor 1 Tahun 2014 tentang Pemilihan Gubernur, Bupati dan Walikota menjadi Undang-Undang terhadap Undang-Undang Dasar Negara Republik Indonesia Tahun 1945, 8 Juli 2015. 